\title{
NUTRIENTS ASSESSMENT OF TROPICAL SOILS AROUND A MEGA CEMENT FACTORY IN SOUTHWEST NIGERIA
}

\author{
Oluseye Olalekan Oludoye ${ }^{1}$, Lanrewaju Amos Ogunyebi ${ }^{1}$ \\ ${ }^{1}$ Environmental Biology Laboratory, Department of Cell Biology and Genetics, University of Lagos, Akoka, \\ Lagos, Nigeria, e-mail: soludoye@yahoo.com
}

Received: 2016.11 .16 Accepted: 2017.01.06 Published: 2017.03.01

\begin{abstract}
Cement production is renowned for particulate contamination of the environment because of high dust emissions and heavy metals that later deposited in soils, serving as a sink. This study investigated the effect of cement dust pollution on some selected soil nutrients (phosphorous, protein, carbon and nitrogen) of the soil surface around Lafarge cement factory, Sagamu, Ogun State, Nigeria. Fifteen (15) composite topsoil samples of the soil surface were randomly collected in the eastern, western, and southern axes of the factory while control samples were collected $15 \mathrm{~km}$ from the factory. The samples were taken from a depth of 0 to $15 \mathrm{~cm}$ and analyzed for chemical, physical and microbiological properties. Data were analyzed with ANOVA and Duncan Multiple Range Test. The results showed that Total Organic Nitrogen (TON), Total Organic Carbon (TOC) and Heavy Metals decreased with increasing distance from the cement factory while there was increase in the amount of Soil Protein and Soil Phosphorous. In conclusion, the inverse correlation between most of these heavy metals, the $\mathrm{pH}$, and the activities of the soil nutrients are indicative that pollution caused by cement production exhibit a significant effect on soil nutrients and this may invariably affect the quality and condition of the soil of the area.
\end{abstract}

Keywords: nutrient assessment, cement dust, total organic carbon, soil protein

\section{INTRODUCTION}

The modernization and industrialization of developing countries has led to the increased use of fossil fuels and their derivatives. Different industrial activities are degrading various environmental components like water, air, soil and vegetation [Kumar et al., 2008]. As such, developing countries are confronted with the great challenge of controlling the terrestrial pollution, especially in the rapidly growing urban centres. Soil pollution is an important problem in industrial areas which may have an adverse effect on the nutrient composition of surrounding top soils [Cachier et al., 2005].

Undoubtedly, the cement industry is involved in the development of structures in this advanced and modern world because it is the basic ingredient of concrete used in constructing modern edifices and structures. In fact, life without cement in this 21 st century is inconceivable. Cement, however, generates dust during its production [Meo, 2004]. As we know Nigeria is one of the developing countries that have undergone rapid industrialization in the few decades of near past. Besides steel and power the cement production of Nigeria is recognized as one of the most important industries.

However, the rapid and unsafe growth of various industries during the last 50 years has resulted in remarkable deterioration of the environment. Cement industry is one of the 17 most polluting industries listed by the central pollution control board. It is the major source of particulate matter, $\mathrm{SO}_{x}, \mathrm{NO}_{\mathrm{x}}$ and $\mathrm{CO}_{2}$ emissions. Cement dust contains heavy metals like chromium, nickel, cobalt, lead and mercury pollutants hazardous to the biotic environment with impact for vegetation, human health, animal health and ecosystem [Baby et al. 2008]. 
Cement is a fine, gray or white powder which is largely made up of Cement Kiln Dust (CKD), a by-product of the final cement product, usually stored as wastes in open-pits and landfills. Exposure to cement dust for a short period may not cause serious problem, however prolonged exposure can cause serious irreversible damage to plants and animals [Heather, 2003].

The obvious effects of cement dust pollution are the alkalization of the ecosystem and the changing of the chemical and biochemical composition of soil. The main impacts of the cement activity on the environment are the broadcasts of dusts and gases. The pollutant particles can enter into soil as dry, humid or occult deposits and can undermine its physicochemical properties [Laj and Sellegri, 2003]. Thus, cement dust pollution has a negative effect on the physico-chemical properties and the biological activity of the soil.

Soil microbial activity is important for the nutrient biogeochemical cycling and it is negatively affected by the cement dust pollution [Ocak et al., 2004]. The most commonly used microbial activity indicators for soil health monitoring are microbial biomass, soil respiration and soil enzyme activity [Nielsen and Winding, 2002]. Microorganisms are the main source of enzymes in soils. It is well known that all biochemical reactions are catalyzed by enzymes, which are proteins with catalytic properties owing to their power of specific activation. Soil enzyme activities are often used as indices of microbial growth and activity in soils.

Enzyme activities play key roles in the biochemical functioning of soils, including soil organic matter formation and degradation, nutrient cycling, and decomposition of xenobiotics [Acosta-Martínez et al., 2007]. Their activity may correlate well with nutrient availability and soil fertility [Nannipieri et al., 2003; Baum et al., 2003]. Soil enzymatic activities depend on optimum conditions of moisture, $\mathrm{pH}$, temperature and substrate concentration.

Soil $\mathrm{pH}$ can affect enzyme activity by influencing the concentration of inhibitors or activators in the soil solution and the effective concentration of the substrate. Enzymatic activities may vary under stress when soil is contaminated by heavy metals [Dick et al., 2000]. Cement dust is also likely to affect both terrestrial and aquatic organisms like fishes, horticultural and other crops through changes in soil chemical properties.

Organic matter in soils and sediments is widely distributed over the earth's surface occur- ring in almost all terrestrial and aquatic environments. Soils and sediments contain a large variety of organic materials ranging from simple sugars and carbohydrates to the more complex proteins, fats, waxes, and organic acids. The determination of total organic carbon (a measure of one of the chemical components of organic matter that is often used as an indicator of its presence in a soil or sediment) is an essential part of any site characterization since its presence or absence can markedly influence how chemicals will react in the soil or sediment. Soil and sediment total organic carbon (TOC) determinations may be used qualitatively to assess the nature of the sampling location (e.g. depositional area) or may be used to normalize portions of the analytical chemistry data set (e.g., equilibrium partitioning).

It has also been revealed that people of cement dust zone are badly affected by respiratory problems, gastro intestinal diseases etc. [Adak et al., 2007]. Several studies have also demonstrated linkages between cement dust exposure, chronic impairment of lung function and respiratory symptoms in human population. Also, dust from cement industry cause irritation of skin.

In contrast, Wu et al. [2010] has stated that more studies and practices have shown that such results from risk assessment have little capability to reveal the real degree of the potential toxic effects of metals without primary empirical research. Though there are some published literatures on heavy metal pollution of the air and dusts surrounding the Lafarge cement factory in southwest Nigeria [Gbadebo and Bankole, 2007], the impact and concentrations of heavy metals in soil nutrients have not been assessed comprehensively.

Therefore, the objective of this study was to assess the soils nutrients status at different locations around a mega cement factory in Sagamu, Ogun State, Nigeria. The study could give an indication of the soil management practices to be adapted and possible remediation measures to be taken to maintain the fertility of the soils for improved crop production in the area.

\section{MATERIALS AND METHODS}

\section{The study area}

The study was carried out in the Lafarge cement factory which is situated in Sagamu, southwest Nigeria $\left(6^{\circ} 50^{\prime} 7^{\circ} 00^{\prime} \mathrm{N} ; 3^{\circ} 45^{\prime} 4^{\circ} 00^{\prime} \mathrm{E}\right)$. The factory is located $72 \mathrm{~km}$ southeast of Ibadan 
(largest city in West Africa), $32 \mathrm{~km}$ west of Ijebu Ode, $63 \mathrm{~km}$ southeast of Abeokuta and $67 \mathrm{~km}$ northwest of Lagos (Figure 1). The factory was established, commissioned and became fully operational in 1978 with the present production capacity of 900000 tonnes/year [Lafarge Cement WAPCO PLC, 2011].

The area is characterized by high annual temperature, high rainfall, high evapotranspiration and high relative humidity which classify it as humid tropical region [Ogunkunle and Fatoba, 2014]. The soil type of Sagamu is Ferralitic and Ferruginous [Ilalokhoin et al., 2013]. The climate is classified as humid tropical climatic zone and controlled by the Tropical Maritime and Tropical Continental air masses [Ilalokhoin et al., 2013]. The mean annual rainfall of Shagamu for 2015 was $1100 \mathrm{~mm}$ [NIMET, 2015].

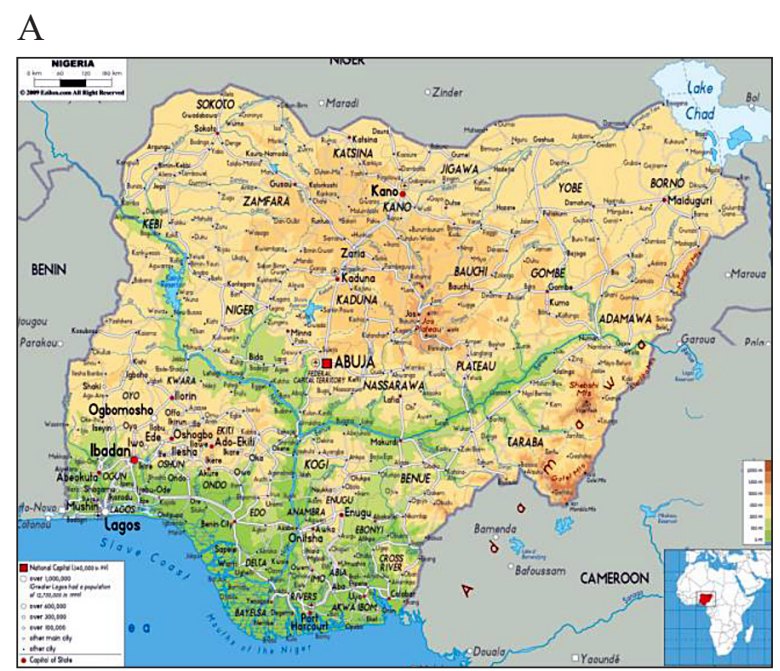

B

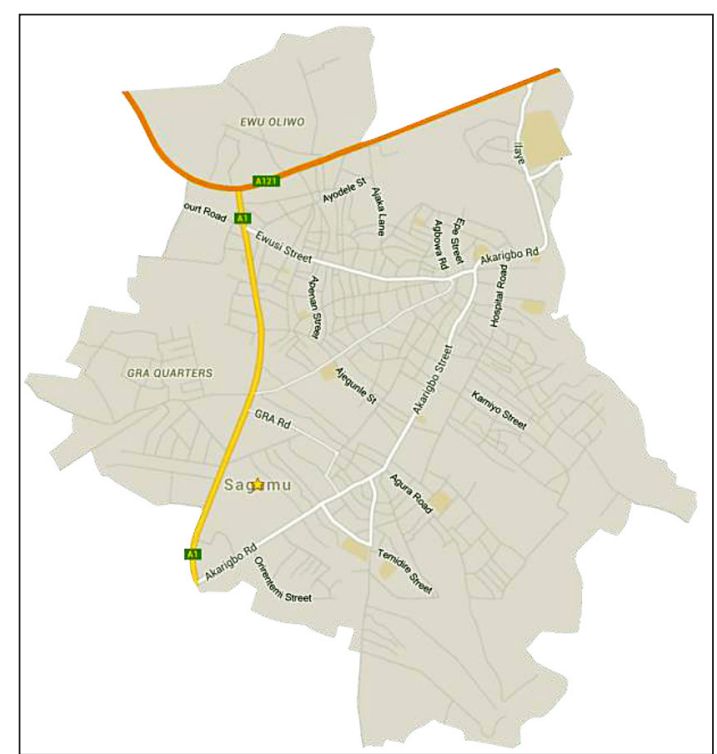

\section{Collection of samples}

Sampling was carried out during the wet seasons of 2015 in the areas surrounding the factory excluding the northern part of the factory due to the presence of swamps. Sampling was carried out on the following dates: $19^{\text {th }}$ August, $2^{\text {nd }}$ September and $18^{\text {th }}$ October, 2015 between 10:00 am and 1:00 pm each day respectively.

At each sampling location, three subsamples were collected at the depth of $0-15 \mathrm{~cm}$ within $10 \mathrm{~m}$ radius of a point using a soil auger. The samples were bulked together to obtain a composite sample and recorded against the coordinate position. A total of 15 composite topsoil samples were collected in the western, the southern and the eastern parts at $100 \mathrm{~m}, 200$ $\mathrm{m}, 300 \mathrm{~m}, 500 \mathrm{~m}$ and $1000 \mathrm{~m}$ distance from the factory respectively. The coordinates at ev-

$\mathrm{C}$

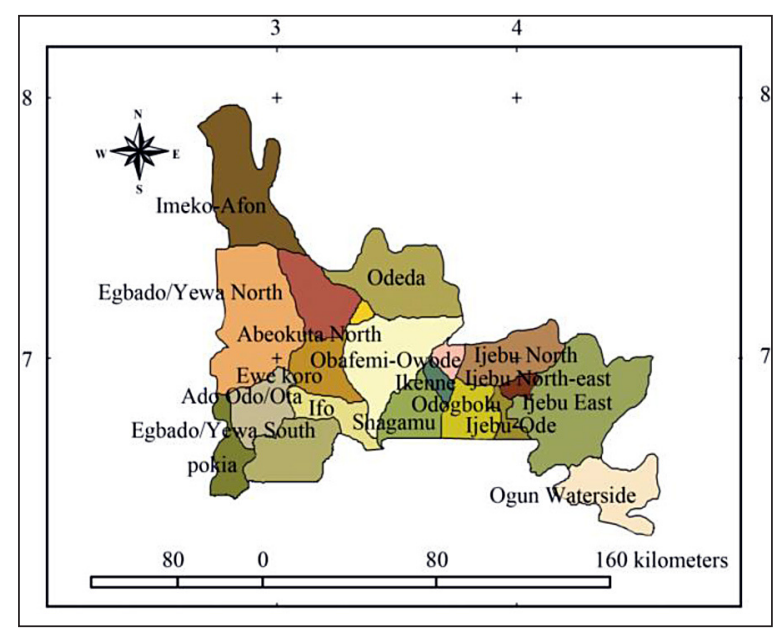

D

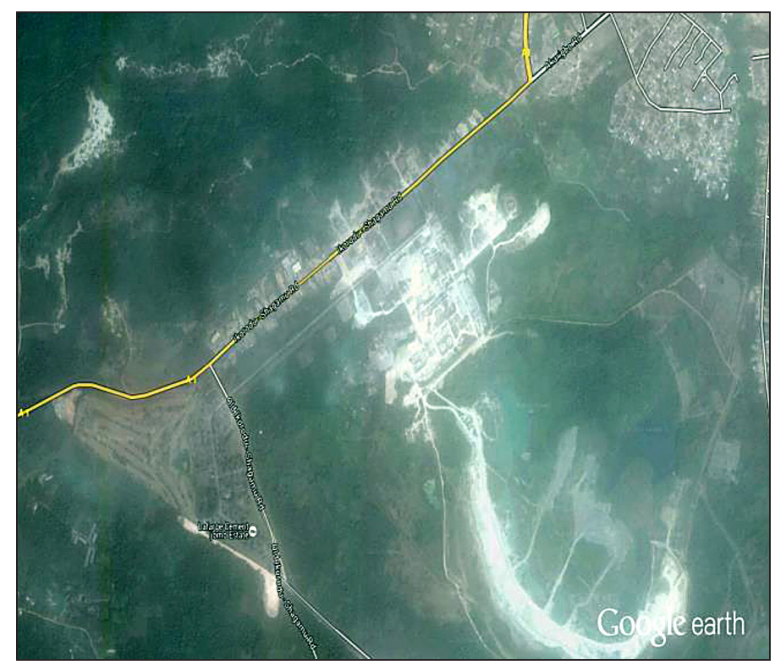

Figure 1. A - map of Nigeria, B - Google map of Sagamu Area, C- map of Ogun state, Nigeria, D - Google map of Lafarge factory (white) and sampling locations 
ery sampling points were taken by a hand-held GPS (Garmin 2H).

Control samples were collected at a distance of about $15 \mathrm{~km}$ from the cement factory where there was no record of cement dust pollution. The soil samples collected were placed in polyethylene bags, properly labeled and transported to the laboratory. Before chemical analysis in the laboratory, the soil samples were air-dried, sieved through a $2-\mathrm{mm}$ sieve mesh to remove coarse material and debris, and pulverized into powder.

\section{Biochemical and physico-chemical analysis of the soil}

Topsoil samples were then analyzed for various soil chemical properties; Soil reaction $(\mathrm{pH})$ was determined potentiometrically in $1: 2.5$ soil to $0.01 \mathrm{M} \mathrm{CaCl}_{2}$ solution ratio (which gives $\mathrm{pH}$ values closer to soil condition than in water) using $\mathrm{pH}$ meter. Total nitrogen was determined using Kjeldahl digestion method (Jackson, 1962), available phosphorus was determined using Bray No.1 method (using $\mathrm{HCl}$ and ammonium fluoride extract) [Bray and Kurtz, 1945], organic carbon was determined by dichromate oxidation method [Figueiredo et al., 2014]; cation exchange capacity was determined by the neutral ammonium acetate saturation method buffered at pH 7 [Kundsen et al., 1982].

The extract for CEC determination was reserved for exchangeable bases determination; flame photometer was used to determine exchangeable potassium and sodium; while exchangeable calcium and magnesium were determined using EDTA method [Devis and Feitas, 1970]. Particle size analysis was carried out using the method of Kettler et al. [2001] and the textural classes determined using the textural triangle.

\section{Statistical analysis}

Statistical analysis was done for soil sample data using repeated measures of Analysis of Variance (ANOVA) to test for significance among the different distances and the control location; and the difference among treatment means were separated using Dunnett's multiple comparison tests $(\mathrm{p} \leq 0.05)$.

In addition, Spearman Rank Correlation analysis was also employed to determine the relationships existing among the metals, the $\mathrm{pH}$, the microbial population, and soil nutrient content. SPSS 20.0 package was used for all statistical tests.

\section{RESULTS AND DISCUSSION}

The effect of the dust on total organic carbon, total nitrogen, soil protein and available phosphorus was found to be statistically significant $(p<0.05)$ (Figures 2-4, Table 1).

\section{Discussions}

At $(p<0.05)$, the results from the Analysis of Variance (ANOVA) showed that there were significance mean differences between the soil samples taken at varying distances and the control sample for all the heavy metals; for all the soil nutrients except Total Organic Nitrogen $(f=$ 0.19 ), for all the soil physiochemical properties except $\mathrm{pH}$ values $(f=0.27)$ and lastly significant for all the microbial population constituents.

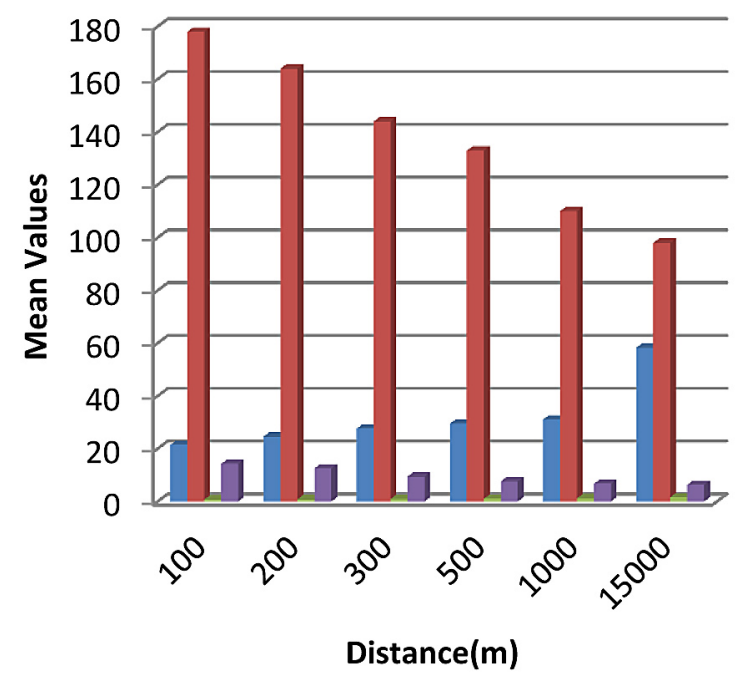

$\square$ Available Phosphorous (ppm)

$\square$ Organic Nitrogen $(\mathrm{mg} / \mathrm{kg}$ )

Protein $(\mathrm{g} / \mathrm{kg})$

$\square$ Total Organic Carbon (\%)

Figure 2. Clustered bar chart showing the mean values of selected soil nutrients with respect to distance 


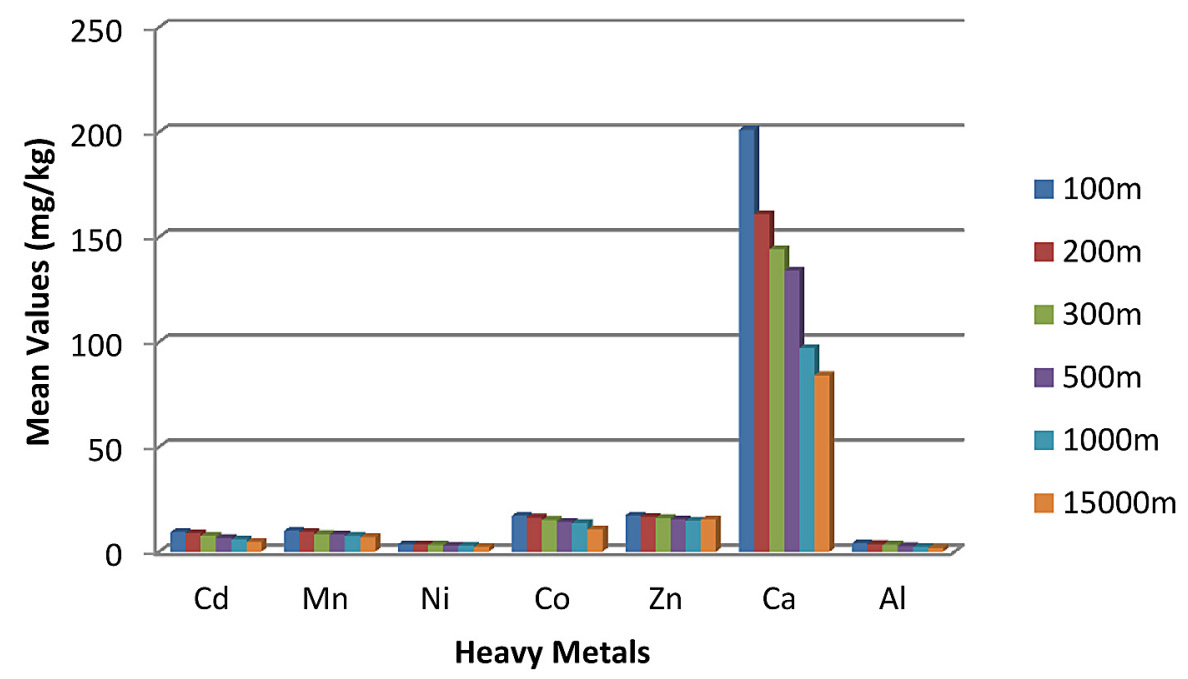

Figure 3. Shows the mean value of heavy metal concentrations in the soil around the factory.

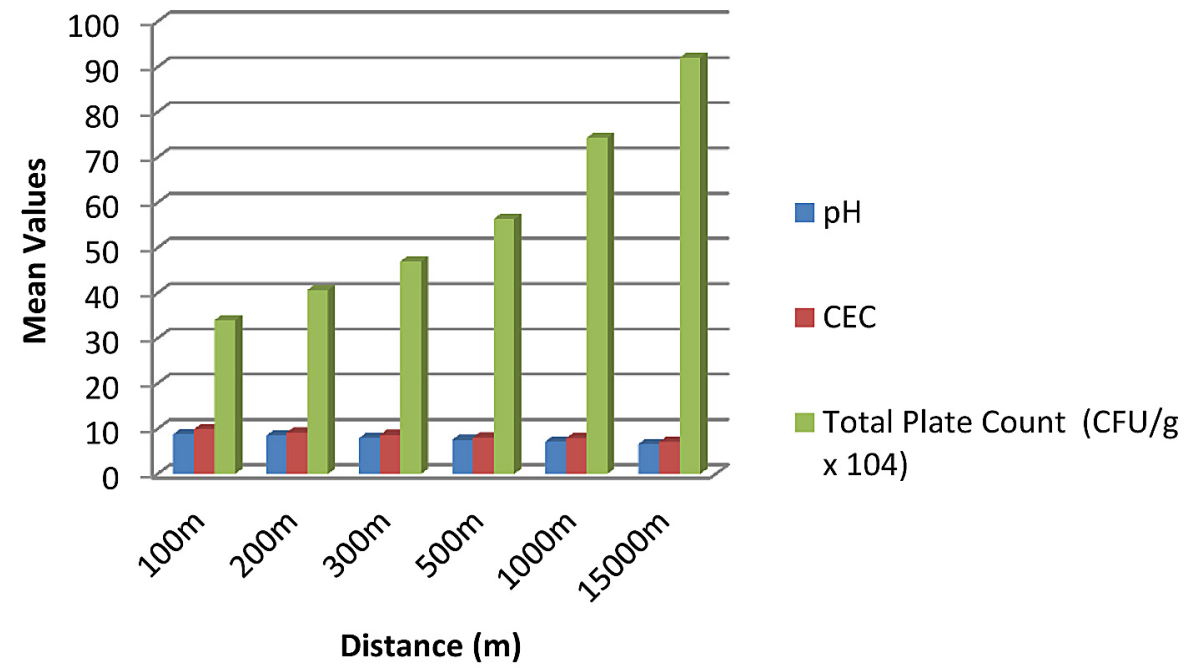

Figure 4. Shows the cation exchange capacity (CEC), the $\mathrm{pH}$ and the total plate count of the soils around the factory

A further analysis carried out using Dunnett's Multiple Comparison tests revealed that for $\mathrm{Cu}$ and $\mathrm{Mn}$, there was no significant difference in the means soil samples at $300 \mathrm{~m}, 500 \mathrm{~m}, 1000 \mathrm{~m}$ compared to the control at $15000 \mathrm{~m} . \mathrm{Cd}$ and Ca metal mean soil samples were not significant at $500 \mathrm{~m}$ and $1000 \mathrm{~m}$ only. $\mathrm{Zn}$ metal presence showed no significant difference at $200 \mathrm{~m}, 300 \mathrm{~m}, 500 \mathrm{~m}$, and $1000 \mathrm{~m}$ compared to the control at $15000 \mathrm{~m}$. Al metal showed no significance difference at 1000 $\mathrm{m}$ to the control sample.

For the soil nutrients, Dunnett's Multiple Comparison tests revealed that for Organic Nitrogen, there were no significant differences between the means for all the soil samples taken at varying distances and the control sample taken at $15000 \mathrm{~m}$. However, the available phosphorus in the treatment samples at all varying distances showed a significant mean difference to the control at $15000 \mathrm{~m}$. The protein content revealed a significant difference at $100 \mathrm{~m}, 200 \mathrm{~m}, 300 \mathrm{~m}$ and 500 m only. Lastly, Total Organic Carbon was not significant at $300 \mathrm{~m}, 500 \mathrm{~m}$ and $1000 \mathrm{~m}$ only.

For the soil physiochemical properties, the $\mathrm{pH}$ values taken from samples at varying distances all showed significant differences to the sample taken at the control distance of $15000 \mathrm{~m}$. The mean Moisture content was significant at $1000 \mathrm{~m}$ only to the control. The temperature values also showed significant differences at $500 \mathrm{~m}$ and 1000 $\mathrm{m}$ when compared to the control.

The concentration of organic carbon and organic nitrogen at the control site was lower than the affected areas; $6.30 \pm 0.20 \%$ and $98.00 \pm 4.00$ $\mathrm{mg} \cdot \mathrm{kg}^{-1}$ respectively while the concentration of the available phosphorous and soil protein was 
Table 1. Correlations between soil nutrients, $\mathrm{pH}$ and physiochemical properties at varying distances

\begin{tabular}{|c|c|c|c|c|c|c|c|c|c|c|c|c|}
\hline & & Distance & TAP & TAN & TP & TOC & $\mathrm{pH}$ & Moisture & Temp. & TPC & FC & Mould \\
\hline \multirow{2}{*}{ Distance } & Correlation Coefficient & 1.000 & & & & & & & & & & \\
\hline & Sig. (2-tailed) & . & & & & & & & & & & \\
\hline \multirow{2}{*}{ TAP } & Correlation Coefficient & $.900^{* *}$ & 1.000 & & & & & & & & & \\
\hline & Sig. (2-tailed) & .000 & . & & & & & & & & & \\
\hline \multirow{2}{*}{ TAN } & Correlation Coefficient & $-.807^{* *}$ & $-.780^{* *}$ & 1.000 & & & & & & & & \\
\hline & Sig. (2-tailed) & .000 & .000 & . & & & & & & & & \\
\hline \multirow{2}{*}{ TP } & Correlation Coefficient & $.881^{* *}$ & $.822^{* *}$ & $-.488^{*}$ & 1.000 & & & & & & & \\
\hline & Sig. (2-tailed) & .000 & .000 & .040 & . & & & & & & & \\
\hline \multirow{2}{*}{ TOC } & Correlation Coefficient & $-.843^{* *}$ & $-.651^{* *}$ & $.710^{* *}$ & $-.602^{* *}$ & 1.000 & & & & & & \\
\hline & Sig. (2-tailed) & .000 & .003 & .001 & .008 & . & & & & & & \\
\hline \multirow{2}{*}{$\mathrm{pH}$} & Correlation Coefficient & $-.841^{* *}$ & $-.949^{* *}$ & $.695^{* *}$ & $-.795^{* *}$ & $.649^{* *}$ & 1.000 & & & & & \\
\hline & Sig. (2-tailed) & .000 & .000 & .001 & .000 & .004 & & & & & & \\
\hline \multirow{2}{*}{ Moisure } & Correlation Coefficient & $.956^{* *}$ & $.804^{* *}$ & $-.858^{* *}$ & $.752^{* *}$ & $-.841^{* *}$ & $-.708^{* *}$ & 1.000 & & & & \\
\hline & Sig. (2-tailed) & .000 & .000 & .000 & .000 & .000 & .001 & . & & & & \\
\hline \multirow{2}{*}{ Temperature } & Correlation Coefficient & $-.914^{* *}$ & $-.733^{* *}$ & $.846^{* *}$ & $-.685^{* *}$ & $.901^{* *}$ & $.698^{* *}$ & $-.933^{* *}$ & 1.000 & & & \\
\hline & Sig. (2-tailed) & .000 & .001 & .000 & .002 & .000 & .001 & .000 & . & & & \\
\hline \multirow{2}{*}{ TPC } & Correlation Coefficient & $.988^{* *}$ & $.843^{* *}$ & $-.764^{* *}$ & $.886^{* *}$ & $-.835^{* *}$ & $-.774^{* *}$ & $.963^{* *}$ & $-.913^{* *}$ & 1.000 & & \\
\hline & Sig. (2-tailed) & .000 & .000 & .000 & .000 & .000 & .000 & .000 & .000 & & & \\
\hline \multirow{2}{*}{$\mathrm{FC}$} & Correlation Coefficient & $.933^{* *}$ & $.844^{* *}$ & $-.944^{* *}$ & $.693^{* *}$ & $-.846^{* *}$ & $-.773^{* *}$ & $.940^{* *}$ & $-.938^{* *}$ & $.910^{* *}$ & 1.000 & \\
\hline & Sig. (2-tailed) & .000 & .000 & .000 & .001 & .000 & .000 & .000 & .000 & .000 & . & \\
\hline \multirow{2}{*}{ Mould } & Correlation Coefficient & $.961^{* *}$ & $.869^{* *}$ & $-.795^{* *}$ & $.842^{* *}$ & $-.844^{* *}$ & $-.783^{* *}$ & $.917^{* *}$ & $-.875^{* *}$ & $.953^{* *}$ & $.921^{* *}$ & 1.000 \\
\hline & Sig. (2-tailed) & .000 & .000 & .000 & .000 & .000 & .000 & .000 & .000 & .000 & .000 & . \\
\hline
\end{tabular}

** Correlation is significant at the 0.01 level (2-tailed).

* Correlation is significant at the 0.05 level (2-tailed).

higher at the control than the areas surrounding the factory. The available phosphorus was low in concentration according to the rating of Esu [1991]; the values conform to the findings of Landon [1991]. The effect could be linked to the impact of the dust on microbial activities as a result of the high $\mathrm{pH}$ induced or possible toxic effect of heavy metals which are established component of the dust [Adejumo et al., 1994]. Microorganism activity was affected negatively by cement pollution and the other environmental conditions resulting from cement pollution; it most likely would have negative effects on the other ecosystem functions [Nowak et al. 2003; Ocak et al. 2004].

In addition, the lower level of available phosphorus, particularly in the affected areas could be due to phosphorus fixation into unavailable forms, such as calcium phosphates [Brady and Weil, 1999], which could be attributed to large quantities of calcium deposited in the highly dusted areas. The topsoil at the control site $(0-15 \mathrm{~cm})$ had higher organic carbon and available phosphorus concentrations compared to the topsoil around the factory. This could be connected with higher level of organic matter and microbial activity inherent in topsoils relative to subsoil, which will equally be relatively effected by of the dust.

The effect of the dust on soil $\mathrm{pH}$, cation exchange capacity and exchangeable bases was also found to be significant $(p<0.01)$. The $\mathrm{pH}$ was slightly acidic in the control and alkaline in the soil samples surrounding the factory. The cation exchange capacity according to the rating of Esu [1991], were also found to be higher in the areas affected by the dust and lowest in the control site. And this clearly corresponds to the proximity of the various areas to the source of the dust; this is in line with the findings of Dick et al. [2000]. The effect on soil $\mathrm{pH}$ could be attributed to the liming effect of the dust, given its calcic and dolomitic limestone content.

Similarly, the effect on exchangeable bases could be due to their accumulation in the affected areas being components of the dust [Ibrahim and Noma, 1994], subsequently leading to higher 
CEC [Sivakumar and Britto, 1995; Singh, 1998]. The difference in $\mathrm{pH}$ was statistically significant $(p>0.05)$ between the area around factory and the control site; also, CEC and all the exchangeable bases were statistically significant $(p<0.05)$. This could be because the topsoil is the immediate recipient of the dust, thus having an advantage over the subsoil, where it gradually leaches down.

The interaction between the locations and all the parameters determined were also found to be significant $(p<0.05)$, indicating a relationship between them in terms of the influence of the dust.

\section{CONCLUSION AND RECOMMENDATION}

\section{Conclusion}

The determination of total organic carbon is an essential part of any site characterization or ecological assessment since its presence or absence can markedly influence how chemicals will react in the soil or sediment. Numerous methods are available for the determination of total organic carbon (TOC) in soils and sediments. These methods may be qualitative, semi-quantitative, or quantitative depending upon the technique used.

A significant effect of cement dust on soil surface was obtained at the different locations around the cement factory. Organic carbon and available phosphorus both decreased and was attributed to the negative effect of dust on microbial population and hence, organic matter decomposition rate; while soil $\mathrm{pH}, \mathrm{CEC}$ and exchangeable bases increased with increasing dust accumulation (proximity to the production area), which could be attributed to the established contents of the dust.

Thus cement dust has a tendency to adversely affect the fertility status of the soils including essential chemical properties as organic carbon (OC) and available phosphorus, especially when large in quantities. The location of farmlands away from the source of the dust, incorporation of good sources of organic matter and application of nitrogenous and phosphatic fertilizers to supplement the fertility status of the soils would improve the fertility of the soils.

\section{Recommendations}

1. There is a need for further research to quantify the effect of the cement dust on soil chemical and physical properties under more controlled experimental conditions
2. Farming activities should be discouraged within a radius of 10 kilometers of the vicinity of the factory because there is every possibility of great uptake of these heavy metals by crops planted, which will eventually reach up the food chain to humans.

3. Efforts should be made by the factory management to bioremediate some metal contents of the soils so as to reduce ecotoxicological problems.

4. Monitoring and environmental audit of production by the designated authority in charge of the environment should spring into action to boast the environmental quality of this area.

5. Further research should be carried out to determine the potential risk of these heavy metals to crops and humans in this area.

6. It is highly recommended that remediation processes be initiated in the area to reduce level of heavy metals in the topsoil around the Lafarge-WAPCO facility, especially $\mathrm{Cd}$ and Cr contents.

7. An assessment of human exposure risks, based on actually measured contaminant concentrations in locally grown vegetables using the standard HESP (Human Exposure to Soil Pollutants) exposure model should be carried out to assess other routes of exposure apart from soil ingestion.

8. It is also imperative to initiate research into the disease prevalence among the inhabitants to determine if there is any link to heavy metal contamination.

\section{REFERENCES}

1. Acosta-Martínez V., Cruz L., Sotomayor-Ramírez D. and Pérez-Alegría L. 2007. Enzyme activities as affected by soil properties and land use in a tropical watershed. Applied Soil Ecology, 35, 35-45.

2. Adak M.D., Adak S. and Purohit K.M. 2007. Ambient air quality and health hazards near min-cement plants. Pollution Research, 26(3), 361-364.

3. Adejumo J.A., Obioh I.B., Ogunsola O.J., Akerede F.A., Olaniyi H.B., Asubiojo O.I., Oluwole A.F., Akanle O.A. and Spyrou N.M.S. 1994. The atmospheric deposition of major, minor and trace elements within and around three cement factories. Journal of Radio Analyt. and Nuclear Chem., 179(2), 195-204.

4. AOAC 1990. Official Methods of Analysis. Association of Analytical Chemists (15th edition). USA, VA., 1-34. 
5. Baby S., Singh N.A., Shrivastava P., Nath S.R., Kumar S.S., Singh D. and Vivek K. 2008.»Impact of dust emission on plant vegetation of vicinity of cement plant. Environmental Engineering and Management Journal, 7(1), 31-35.

6. Baum C, Leinweber P. and Schlichting A. 2003. Effects of chemical conditions in re-wetted peats temporal variation in microbial biomass and acid phosphatase activity within the growing season. Applied Soil Ecology, 22, 167-174.

7. Bray R.H. and Kurtz L.T. 1945. Determination of total organic and available forms of phosphorus in soils. Soil Science, 59, 39-45.

8. Cachier H., Aulagnier F., Sarda R., Gautier F., Masclet P. and Besombes J.L. 2005. The ESCOMPTE experiment: 108 Air. Qual. Atmos. Health, (1), 101-109.

9. Devis J. and Feitas 1970. Physical and chemical Methods of soil and water analyses soil Bulletin no. 10 FAO Rome. Italy.

10. Dick W.A, Cheng L. and Wang P. 2000. Soil acid and alkaline phosphatase activity as $\mathrm{pH}$ adjustment indicators, Soil Biology and Biochemistry, 32, 1915-1919.

11. Esu I.E. 1991. Detailed soil survey of NIHORT Farm at Bunkure, Kano State, Nigeria. Institute for Agricultural Research, Ahmad Bello University, Zaria, Nigeria.

12. Fatoba P.O., Ogunkunle C.O., and Olawepo G.K. 2012. Assessment of atmospheric metal depositions in the industrial areas of the southwest of $\mathrm{Ni}$ geria. Ethiopian Journal of Environmental Studies and Management, 5(3), 269-281.

13. Figueiredo C.C., Sato J.H., Marchão R.L., Madari B.E., Benedito L.E.C., Jader Galba Busato J.G. and de Souza D.M. 2014. Methods of soil organic carbon determination in Brazilian savannah soils. Scientia Agricola. 71(4), 302-308.

14. Heather G. 2003. Effects of Air Pollution on Agricultural Crops. Ministry of Agricultural, Air Pollution on Agricultural Crops, Ontario, Canada.

15. Jackson M.L. 1962. Soil Chemical Analysis. International Institute for Tropical Agriculture (IITA). Manual Series No.1, 70 pp.

16. Kettler T.A., Doran J.W. and Gilbert T.L. 2001. Simplified Method for Soil Particle-Size Determination to Accompany Soil-Quality Analyses.

17. Kumar S.S., Singh N.A., Kumar V., Sunisha B., Preeti S., Deepali S. and Nath S.R. 2008. Impact of dust emission on plant vegetation in the vicinity of cement plant. Environmental Engineering and Management Journal, 7(1), 31-35.

18. Kundsen D., Peterson G.A. and Prett P.F. 1982. Lithium, Sodium, Potassium. In: Methods of Soil Analysis by A.L. Page, R.A.Miller, D.R. Keeney (eds) Part 2 Afron. Amer. Soc. Agron. Inc. Madison Wisconsin, 5-246.

19. Lafarge-WAPCO 2011. Lafarge-WAPCO: Supporting Nigeria's development. Annual Report of Lafarge-Cement WAPCO Nigeria Plc, Nigeria. $32 \mathrm{pp}$.

20. Landon J.R. (Ed.) 1991. Booker tropical soil manual: A Handbook for Soil Survey and Agricultural Land Evaluation in the Tropics and Subtropics ( $\mathrm{p}$. 474). Essex, New York: Longman Scientific and Technical.

21. Meo S.A. 2004. Health hazards of cement dust. Saudi Medical Journal. 25, 1153-1159.

22. Nannipieri P., Ascher J. and Ceccherini M.T. 2003. Microbial diversity and soil functions. European Journal Soil Science, 54, 655-670.

23. Nielsen M.N. and Winding A. 2002. Microorganisms as Indicators of Soil Health. National Environmental Research Institute, Denmark. NERI Technical Report No. 388

24. Ocak I., Sulun Y. and Hasenekoglu I. 2004. The Effect of Cement Dust Emitted From Gaziantep Cement Plant on Microfungus Flora of Surroundings Soils, Turkey. Trakya University Journal of Science, 5, 107-115.

25. Ogunkunle C.O. and Fatoba P.O. 2013. Pollution loads and the ecological risk assessment of soil heavy metals around a mega cement factory in southwest Nigeria. Polish Journal of Environmental Studies, 22(2), 487-493.

26. Singh B.R. 1998. Fertility and Salinity/Sodicity status of the Fadama soils in Kebbi state. A report submitted to the Kebbi Agricultural and Rural Development Authority (KARDA), Kebbi State, Nigeria. pp. 44.

27. Sivakumar S. and Britto A.J. 1995. Effect of cement pollution on soil fertility. Journal of ecotoxicology and environmental monitoring 5 (2), 147-149.

28. Wu Y., Xu Y., Zhang J. and Hu S. 2010. Evaluation of ecological risk and primary empirical research on heavy metals in polluted soil over Xiaoqinling gold mining region, Shaanxi, China. Trans, Nonferrous Met. Soc. China, 20, 688. 